\title{
A study of physico-chemical characteristics of Ugborikoko/Okere stream as an index of pollution
}

\author{
Peretiemo-Clarke, B. O. ${ }^{1 *}$, Balogun, M. A. ${ }^{2}$ and Akpojiyovwi, $0 .{ }^{3}$ \\ ${ }^{1}$ Chemistry Department, Delta State University, Abraka, Delta State, Nigeria. \\ ${ }^{2}$ Delta Steel Company Plc, Ovwian-Aladja, Delta State, Nigeria. \\ ${ }^{3}$ Department of Petroleum Resources, NNPC, Warri Office, Delta State, Nigeria.
}

Accepted 15 June, 2009

\begin{abstract}
A total of 8 samples were collected from strategic points along the Ugborikoko/Okere creek. The levels of the physico-chemical parameters and heavy metal pollutants were determined. Results of both physico-chemical characteristics and heavy metals revealed some degree of pollution in the creek. The mean values of $\mathrm{pH}$, temperature, turbidity, conductivity, total dissolved solids, total suspended solids and chloride were $6.8,30.3^{\circ} \mathrm{C}, 106.53 \mathrm{NTU}, 471.45 \mathrm{ohms} / \mathrm{cm}, 354.56 \mathrm{mg} / \mathrm{l}, 123.56 \mathrm{mg} / \mathrm{l}$ and $78.11 \mathrm{mg} / \mathrm{l}$ respectively. The average value obtained for oil and grease was $14.13 \mathrm{ppm}$. The average value for the heavy metals were $2.258 \mathrm{ppm}$ for iron, $0.0729 \mathrm{ppm}$ for cadmium, $0.4225 \mathrm{ppm}$ for zinc, $0.0997 \mathrm{ppm}$ for manganese, $0.0236 \mathrm{ppm}$ for copper, $0.2117 \mathrm{ppm}$ for nickel. The results obtained indicated a significant level of pollution of the Ugborikoko/Okere creek. It was observed that the levels of iron, lead, chromium, cadmium, manganese and nickel in the samples were not in compliance with recommended standards set by world health organization for inland (fresh) and potable water.
\end{abstract}

Key words: Pollution, physico-chemical, heavy metals, Ugborikoko/Okere Creek

\section{INTRODUCTION}

Water is the world's most precious resource hence the quality of water has been a major factor in determining human welfare throughout history (Agency for Toxic Substances and Diseases Registry, 1993). In addition to having water to drink, people require it for a wide range of uses. This includes domestic purpose such as food preparation, laundry, hygiene purposes, irrigation, manufacturing, transportation, power generation, sports and recreation. In fact, socio-economic progress is impossible without adequate supplies of quality water (Marine Pollution Bulletin, 1986).

Man and his technology has become an enemy of nature. This is evident of his effect on the environment by his agricultural activities, heavy industrial activities, by construction works and other technological advancements. The consequences are introducing toxic chemical substances into the ecosystem resulting in pollution especially the environment (Agency for Toxic Substances

${ }^{*}$ Corresponding tegaperetiemoclarke@yahoo.com. and Diseases Registry, 1993). The practice of indiscriminate disposal of wastes of all types (domestic, municipal, untreated wastes and industrial effluents) in the cities and villages, increasing use of fertilizers and other agricultural chemicals and accelerated erosion suggest strongly, the widespread pollution of streams, rivers, lakes, creeks and lagoons which is confirmed by the visual appearance (coloured water) with offensive odour of these water bodies in most parts of the country (Marine Pollution Bulletin, 1986). Industrial growth has increased water pollution problems. Most of the companies dispose untreated wastes into the environment hence the pollution of their dump site, with offensive odour and is highly coloured (Allen et al., 1974).

Studies showed that most rivers flowing through heavily urbanized and industrialized areas in Nigeria are contaminated with high concentrations of some heavy metals (Marine Pollution Bulletin, 1986). In addition, the untreated effluent is also characterized by a lot of other physico-chemical pollutants such as the heat waste (temperature), acidic/basic nature of the effluent $(\mathrm{pH})$, the turbidity of the effluent, total dissolved solids (TDS), suspended solids, salinity, conductivity, etc. 
Rapid urbanization and industrialization of Warri and its environs between 1968 and 1980 certainly imposed new demands on the Warri river and its tributaries (Agency for Toxic Substances and Diseases Registry, 1993). While rapid industrialization could account for high population growth in Warri and environs (NEST, 1991), poor development planning, chronic unhygienic habits and lack of regulations enforcement have profound opportunities for people to defecate directly and many small industries to dispose untreated wastes into Warri river and its creeks (tributaries) (Environmental Protection Agency,1972).

Warri river stretches within latitudes $5^{\circ} 21^{\prime}$ to $6^{\circ} 00^{\prime} \mathrm{N}$ and longitudes $5^{\circ} 24^{\prime}$ to $6^{\circ} 21^{\prime} \mathrm{E}$. The Ugborikoko/Okere creek as one of its tributaries in Warri is within this geographical position (Environmental Protection Agency, 1972). Warri River is a major river that carries most of the municipal and domestic waste load of Warri and environs and finally flows to the sea. Earlier studies of the river by Egborge and others (Environmental Protection Agency, 1972), revealed that 3 major creeks namely, Miller or Ugborikoko/Okere, Tori and Crawford creeks (tributaries) of Warri river drain Warri town and empty their waters into the main channels of Warri River. The former, the "Miller creek" is the subject of this study. Not much investigation has been carried out on this creek. In spite, of the heavy load of waste it has been handling, hence the need for this study.

Considering the relevant problems associated with growth in population of the Warri metropolis in recent times due to industrialization and the fact that not much investigation has been conducted on this creek (Miller creek), hence the need for this study, which aimed at investigating the levels of pollution in the creek of some named physico-chemical parameters and heavy metals and compare same with standards and more importantly to provide baseline data upon which future computation of the water quality of the creek would be based.

\section{MATERIALS AND METHODS}

\section{Sample collection}

Sampling sites were carefully selected at distances from 100 to 500 $\mathrm{m}$ based on influence on the creek by artisan activities, garbage dumps, domestic wastes, sewage and drains from city, run-offs into the creeks which are the major sources of pollution.

\section{Pretreatment}

The treatment given to samples depends on the nature of the parameter that was under investigation. A total of 48 surface water samples were collected from 7 sampling points along the study creek from source at Ugborikoko/Agaga layout to the point of entering Warri River at Miller jetty and one control point upstream of the Warri river by the NPA/DSC express bridge.

\section{Sample preservation}

6 water samples collected from each sampling points were treated thus: i) Two of the samples were unpreserved and stored immediately after collection in iced cooler at a temperature of $4^{\circ} \mathrm{C}$ as required for physico-chemical processes (Marine Pollution Bulletin, 1986).

ii) Two other samples in glass bottles were preserved with concentrated tetraoxosulphate (vi) acid at $\mathrm{pH}$ of 2 for oil and grease parameter. This was to prevent any trace of oil from adhering to the glass bottles such that all the oil will be in the samples.

iii) The last set of water samples in plastic or polyethylene bottles were immediately acidified to a $\mathrm{pH}$ less than 2.0 with concentrated trioxonitrate $(\mathrm{v})$ acid to prevent possible adsorption of metals on the container walls and in order to obtain total amount of metals (Marine Pollution Bulletin, 1986).

\section{Water analysis}

Physical parameters such as $\mathrm{pH}$, temperature, turbidity and conductivity were determined in-situ immediately after sampling, prior to proper calibration of the various equipment used using standard methods (Akintunde, 1986). Parameters such as colour, odour, clarity or the physical presence of any object were described by visual judgment of the sample like colourless, odourless, etc. The turbidity of the water samples was measured using $\mathrm{HACH}$ MODEL 2100AN TURBIDIMETER. The temperature was measured using mercury in bulb thermometer. The $\mathrm{pH}$ was measured using the Barnat 20 digital $\mathrm{pH}$ meter. Conductivity measurement was carried out using electrolytic conductivity cell $\mathrm{HACH}$ model $\mathrm{CO} 130$. Total dissolved solids (TDS) were determined by the evaporation method. Total suspended solids were determined by the filtration method (Akintunde, 1986). Chloride was measured by the Mohr's method using silver nitrate as titrant (Batley and Gadner, 1977). The method of photometric (API-RD 45, 3.17) was used in determining the oil and grease in water. This was measured by extraction with xylene. Heavy metals in the water samples were determined using buck scientific atomic absorption spectrophotometer MODEL 210 VGA.

\section{RESULTS AND DISCUSSION}

Tables 1 and 2 represent the results of the physicochemical parameters, oil and grease parameters and heavy metals concentrations respectively. The colour of the water samples ranged from slightly brownish and grey to greyish black. This therefore, rendered the water unfit for use in situations where colourless water is required. Also aquatic organisms will be deprived of enough light and proper ecological balance that is expected of the aquatic organism. Most of the water samples had objectionable smell. According to Allen et al. (1974), odour and coloured waters are indications of gross water pollution, which is undesirable to the ecosystem. A temperature range of 28.0 to $32.5^{\circ} \mathrm{C}$ with an average of $30.3^{\circ} \mathrm{C}$ was observed. Temperature values recorded in this study are within recommended WHO standard limits of Table 3 . This implies the absence of thermal pollution in the creek.

The $\mathrm{pH}$ values for the water samples investigated fall into the range of 5.3 to 8.2 with an average of 6.8 which is comparable to specified limits of all the standards stated $(6.5$ - 9.2). The low $\mathrm{pH}$ value of 5.3 recorded at point $\mathrm{H}$ indicates acidity $(\mathrm{pH}<7.0)$. While the high $\mathrm{pH}$ value 8.2 observed at point $\mathrm{C}$ is alkaline or basic $(\mathrm{pH}>$ 
Table 1. Results of physico-chemical parameters in water samples collected from Ugborikoko/Okere creek.

\begin{tabular}{|l|l|l|c|c|c|c|c|c|c|c|}
\hline Loc. & \multicolumn{1}{|c|}{ Colour } & Odour & $\begin{array}{c}\text { Temp } \\
\left({ }^{\circ} \mathbf{C}\right)\end{array}$ & $\mathbf{p H}$ & $\begin{array}{c}\text { Cond. } \\
(\mu \mathbf{m h o s} \\
/ \mathbf{c m})\end{array}$ & $\begin{array}{c}\text { Turbidty } \\
\text { NTU }\end{array}$ & $\begin{array}{c}\text { TDS } \\
\mathbf{m g} / \mathbf{l}\end{array}$ & $\begin{array}{c}\text { Salinity } \\
(\mathbf{m g} \mathbf{C l} / \mathbf{l})\end{array}$ & $\begin{array}{c}\text { TSS } \\
(\mathbf{m g} / \mathbf{l})\end{array}$ & $\begin{array}{c}\mathbf{O} \text { and G } \\
(\mathbf{p p m})\end{array}$ \\
\hline $\mathrm{A}$ & Brownish & Odourless & 28.0 & 6.1 & 220 & 388 & 335 & 70.5 & 368 & 3.21 \\
$\mathrm{~B}$ & Greyish & Objectionable & 29.7 & 6.7 & 239 & 122 & 151 & 20.0 & 145.5 & 15.60 \\
$\mathrm{C}$ & Greyish & Objectionable & 32.5 & 8.2 & 579 & 122.25 & 527 & 32.5 & 234.5 & 26.14 \\
$\mathrm{D}$ & Greyish black & Objectionable & 30.5 & 6.8 & 794 & 68.73 & 34 & 72.6 & 44.5 & 22.34 \\
$\mathrm{E}$ & Greyish black & Objectionable & 29.8 & 7.2 & 687 & 66.28 & 454 & 70.1 & 111 & 25.23 \\
$\mathrm{~F}$ & Slightly brownish & Odourless & 30.0 & 7.2 & 568.5 & 39.35 & 424 & 158.9 & 32.5 & 6.36 \\
$\mathrm{G}$ & Slightly brownish & Odourless & 32.0 & 7.0 & 647 & 41.83 & 468 & 196.5 & 39.5 & 12.31 \\
H & Slightly brownish & Odourless & 30.0 & 5.3 & 37.15 & 43.5 & 43.5 & 3.75 & 13.0 & 1.81 \\
Limits & Colourless & Unobjectionable & 35 & $6.5-8.5$ & & $<10$ & 2000 & 600 & $<30$ & $0.3,10$ \\
\hline
\end{tabular}

$A=$ Source point; $B=$ Willie bridge area; $C=$ Mudiaga Odje junction area; $D=$ Ogboru bridge area; $E=$ Okere road bridge area; $F=$ Mabiaku link road bridge area; $\mathrm{G}=$ Miller Jetty area; $\mathrm{H}=$ Upstream of Warri river by NPA/DSC express bridge area.

Loc = Location; $\mathrm{O}$ and $\mathrm{G}=$ oil and grease $;$ TDS = Total dissolved solids; TSS = total suspended solids; cond = conductivity.

Table 2. Measured values in (ppm) for heavy metal content of the water samples collected from Ugborikoko/Okere creek.

\begin{tabular}{|c|c|c|c|c|c|c|c|c|}
\hline Location & $\mathbf{F e}$ & $\mathbf{P b}$ & $\mathbf{C r}$ & $\mathbf{C d}$ & $\mathbf{Z n}$ & $\mathbf{M n}$ & $\mathbf{C u}$ & $\mathbf{N i}$ \\
\hline $\mathrm{A}$ & 4.458 & $\mathrm{BDL}$ & 0.3 & $\mathrm{BDL}$ & 0.401 & 0.1982 & 0.0118 & 0.2903 \\
$\mathrm{~B}$ & 1.084 & 0.055 & 0.333 & 0.0201 & 0.6010 & 0.0991 & 0.0353 & 0.3440 \\
$\mathrm{C}$ & 2.289 & 0.145 & 0.25 & 0.0561 & 0.3400 & 0.1357 & 0.0254 & 0.1830 \\
$\mathrm{D}$ & 1.265 & 0.1000 & 0.25 & 0.185 & 0.2980 & 0.1806 & 0.0156 & 0.1290 \\
$\mathrm{E}$ & 2.410 & 0.055 & 0.333 & 0.02177 & 0.7380 & 0.0275 & 0.0006 & 0.2903 \\
$\mathrm{~F}$ & 3.374 & 0.0275 & 0.388 & 0.0086 & 0.5150 & 0.0732 & 0.0451 & 0.2365 \\
$\mathrm{G}$ & 1.686 & 0.055 & 0.333 & 0.02170 & 0.395 & 0.0822 & 0.0313 & 0.1827 \\
$\mathrm{H}$ & 1.500 & $\mathrm{BDL}$ & $\mathrm{BDI}$ & 0.0034 & 0.0920 & 0.0009 & $\mathrm{BDL}$ & 0.0376 \\
Limits & 1.0 & 0.001 & 0.03 & 0.001 & 1.0 & 0.05 & 1.5 & $<0.05$ \\
\hline
\end{tabular}

$\mathrm{BDL}=$ Below detectable limits.

7.0). Low $\mathrm{pH}$ may be as a result of accumulation of carbon (iv) oxide due to low phytoplankton density, the influx of humic substances and acid or the discharge of acid base effluents. Conversely, in the dry season, photosynthetic activities reduce free carbon (iv) oxide content resulting in increased $\mathrm{pH}$ values (Lund, 1965). Increase in $\mathrm{pH}$ of rivers during the dry season has been reported by Imevbore (1970) in river Niger at Shagamu and Egborge (1994) in river Oshun. Although there are no data, gas flaring in and around Warri could generate acid rain which in conjunction with humic substances in the industrialized Warri environment could account for the acidic nature of the water (Egborge, 1994). However, the near neutral $\mathrm{pH}$ values (7.0) recorded for most of the locations makes the water suitable as coolant in the industry since it is a running water body.

Values for conductivity ranged from $37.15 \mu \mathrm{hms} / \mathrm{cm}$ to $794 \mu \mathrm{hms} / \mathrm{cm}$. The average conductivity value is 471.45 $\mu \mathrm{ohms} / \mathrm{cm}$ for the stations. Only stations $\mathrm{A}, \mathrm{B}$ and $\mathrm{H}$ fell below the average. The highest $(794 \mu \mathrm{ohms} / \mathrm{cm})$ and lowest $(7.15 \mu \mathrm{ohms} / \mathrm{cm})$ values were obtained from station D (Ogboru bridge) and $\mathrm{H}$ (control by DSC express bridge). These values are indicative of the level of dissolved solids in solution. The conductivity of a water body is an index of the total ionic content and therefore indicates freshness or otherwise of the water body. For many Nigerian inland water bodies, the conductivities are much less than 500 or $5000 \mu \mathrm{ohms} / \mathrm{cm}$ at the peak of the dry season and much less than 100 or $1000 \mu \mathrm{hms} / \mathrm{cm}$ during the raining season. Generally, waters with conductivity values below $1000 \mu \mathrm{scm}^{-1}$ are fresh. Conductivities above $40,000 \mu \mathrm{scm}^{-1}$ indicate marine waters and those between these 2 limits are brackish (Egborge, 1994). This information suggests that the Ugborikoko Okere creek as flowing and partial tidal could be fresh and brackish.

The turbidity values obtained were of the range 4.33 to 388 NTU with an average value of 106.53 NTU. All values obtained exceeded specified limits of $<10$ NTU in Table 3. This therefore is an indication that the creek is 
Table 3. Limits for substances and characteristics affecting the acceptability of water domestic use (WHO Standards, 1971).

\begin{tabular}{|l|c|c|}
\hline \multicolumn{1}{|c|}{$\begin{array}{c}\text { Substances/ } \\
\text { characteristics }\end{array}$} & $\begin{array}{c}\text { Highest desirable } \\
\text { level }\end{array}$ & $\begin{array}{c}\text { Maximum permissible } \\
\text { level }\end{array}$ \\
\hline Total solids & $500 \mathrm{mg} / \mathrm{l}$ & $1,500 \mathrm{mg} / \mathrm{l}$ \\
pH range & 7.0 to 8.5 & 6.5 to 9.2 \\
Mineral oil & $0.01 \mathrm{mg} / \mathrm{l}$ & $0.3 \mathrm{mg} / \mathrm{l}$ \\
Phenoic compounds & $0.001 \mathrm{mg} / \mathrm{l}$ & $0.002 \mathrm{mg} / \mathrm{l}$ \\
Chloride as Cl & $200 \mathrm{mg} / \mathrm{l}$ & $600 \mathrm{mg} / \mathrm{l}$ \\
Copper as $\mathrm{Cu}^{++}$ & $0.05 \mathrm{mg} / \mathrm{l}$ & $1.5 \mathrm{mg} / \mathrm{l}$ \\
Iron as $\mathrm{Fe}^{++}$ & $0.1 \mathrm{mg} / \mathrm{l}$ & $1.0 \mathrm{mg} / \mathrm{l}$ \\
Zinc as $\mathrm{Zn}^{++}$ & $5.0 \mathrm{mg} / \mathrm{l}$ & $15 \mathrm{mg} / \mathrm{l}$ \\
Sulphate as $\mathrm{SO}_{4}$ & $200 \mathrm{mg} / \mathrm{l}$ & $400 \mathrm{mg} / \mathrm{l}$ \\
Total hardness $\mathrm{CaCO}_{3}$ & $100 \mathrm{mg} / \mathrm{l}$ & $500 \mathrm{mg} / \mathrm{l}$ \\
Calcium as $\mathrm{Ca}^{++}$ & $75 \mathrm{mg} / \mathrm{l}$ & $200 \mathrm{mg} / \mathrm{l}$ \\
Magnesium as $\mathrm{Mg}^{++}$ & $30 \mathrm{mg} / \mathrm{l}$ & $150 \mathrm{mg} / \mathrm{l}$ \\
Manganese as $\mathrm{Mn}^{++}$ & $0.05 \mathrm{mg} / \mathrm{l}$ & $0.5 \mathrm{mg} / \mathrm{l}$ \\
Anionic detergents & $0.2 \mathrm{mg} / \mathrm{l}$ & $1.0 \mathrm{mg} / \mathrm{l}$ \\
Colour & $5 \mathrm{units}$ & $50 \mathrm{units}$ \\
Odour & Unobjectionable & Unobjectionable \\
Tastes & - do- & -do- \\
\hline
\end{tabular}

highly turbid such that passage of light into the water will be hampered. This will adversely affect the ecological balance of the ecosystem.

Suspended and dissolved solids are common tests of polluted waters. However, total dissolved solids values obtained from the tests ranged from 43.5 to $527 \mathrm{mg} / \mathrm{l}$ with an average value of $354.56 \mathrm{mg} / \mathrm{l}$. Point $\mathrm{H}$ recorded the least value while point $C$ had the highest value. Values for total suspended solids ranged from 13.0 to $368 \mathrm{mg} / \mathrm{l}$ and an average value $F$ of $123.56 \mathrm{mg} / \mathrm{l}$. The average value is very much in the excess of the limits of $<30 \mathrm{mg} / \mathrm{l}$ for inland waters. This infers that the creek under study is highly polluted with suspended solids from runoffs and domestic sewage which prevents the use of light by aquatic lives. The adverse effect will certainly reflect on the food chain.

Chloride concentrations range between 3.75 and 196.5 $\mathrm{mg} / \mathrm{l}$ with an average value of $18.11 \mathrm{mg} / \mathrm{l}$. The chloride contents increased towards the Miller Jetty, an indication of the effects of the Warri river intrusion. However, values obtained compared favourably with WHO standards of $600 \mathrm{mg} / \mathrm{l}$ maximum permissible limits indicating that the water body could not have been polluted with the chloride content.

For oil and grease, values obtained were between 1.81 and $25.23 \mathrm{ppm}$ and with an average value of $14.13 \mathrm{ppm}$. Areas with high values (B, C, D and E) are inline with the prevailing activities of artisans (vehicle mechanic workshops) who use engine oils to service car engines. These values have not compared favourably with recommended standards of $10 \mathrm{ppm}$ for inland waters and indicate pollution of the water body by oil and grease. Oil and grease as a pollutant interferes with aerobic and anaerobic biological processes leading to imbalance of the ecosystem (Apha, 1980).

Measured values of iron water ranged from 1500 and $4.458 \mathrm{ppm}$ and average value of $2.258 \mathrm{ppm}$. These values are a lot in excess of the WHO recommended water and inland waters. The high values could be due to the activities of metal works, use of fuel pigments and paints along the creek and effluent or domestic sewage from rusted pipes and iron in garbage dumps, which find their way into the stream. Lead concentrations for the samples range between non-detectable for points $A$ and $\mathrm{H}$ to $0.145 \mathrm{ppm}$ in point $\mathrm{C}$ with an average value of $0.0729 \mathrm{ppm}$. All values obtained in the study are in excess of recommended limits of $0.001 \mathrm{mg} / \mathrm{l}$ of WHO. Activities of vehicle mechanics with leaded fuel, refinery products, use of fertilizers by local farmers, small plastic industries, alloys and solders, paints and pigments and battery chargers, deposits of car exhaust, etc all along the creek may have contributed to the level of lead pollution recorded.

The chromium concentration recorded ranged from non-detectable to $0.388 \mathrm{ppm}$ with an average of 0.312 ppm. Measured chromium values have not met with WHO standards of $0.05 \mathrm{mg} / \mathrm{l}$. The heavy chromium level on the creek could be due to run offs from local farmlands/garden and from car spray and wood works as chromium is one of the components. Measured values of cadmium range from non-detectable to $0.0561 \mathrm{ppm}$ and an average of $0.0215 \mathrm{ppm}$. Zinc values range from 0.00920 to $0.7380 \mathrm{mg} / \mathrm{l}$ with an average of $0.4225 \mathrm{ppm}$. The low zinc values suggested no zinc pollution. Runoffs 
from batteries and other electrical appliances, paints and pigments, pesticides, herbicides, fertilizers, etc along the course of the creek are some contributors to the level of zinc. Manganese concentrations in the samples investtigated were between 0.0009 and $0.1806 \mathrm{ppm}$ with an average value of $0.0997 \mathrm{ppm}$. The values obtained did not comply with WHO recommended value for domestic water $(0.05 \mathrm{mg} / \mathrm{l})$ suggesting the creek to be significantly polluted with it. The sources of manganese pollution into the stream could be due to runoffs from activities of artisans. Measured values of copper range from nondetectable to $0.0451 \mathrm{ppm}$ with the average value of $0.0236 \mathrm{ppm}$. The trace values obtained suggest the precipitation sources of copper into the creek could be from runoffs with activities of artisans. Recorded values for nickel were between 0.0376 and $0.03440 \mathrm{ppm}$ with an average value of $0.2117 \mathrm{ppm}$. These values indicate possible nickel pollution from activities of artisans.

\section{Conclusion}

Available results have indicated that the creek is significantly polluted with some of the physico-chemical parameters and heavy metals investigated and most values did not satisfy the limits of recommended stand-ards. Activities of artisans along the creek, runoff from untreated domestic and local farmlands, leachates from garbage dumps and indiscriminate dumping of wastes into the water body could possibly be responsible for the pollution level. From this study and many others, it has been established that the activities of man due to Industrialization and urbanization are causes of pollution.

\section{REFERENCES}

Allen FS, Grismshan MH, Parkinson J, Quarmbyc A (1974). Chemical Analysis of Ecological Materials. Blackwell Scientific London, pp. 340-389.

Akintunde I (1986). Management and Disposal of Industrial Waste in Nigeria. Symposium on Plant Sanitation and Industrial Waste Disposal. University of Ibadan. Ibadan. 9th-13th September, 1986.

Apha (1980). Standard Methods for the Examination of Water and Wastewater 15th Edition, American Public Health Association,

American Water Works Association, Water Pollution Control Federation. Environmental Protection Agency (EPA) (1972). Helena Valley, Montag Area Environmental Pollution Study. USA.

Egborge ABM (1994). Water Pollution in Nigeria Vol. 1 Biodiversity and Chemistry of Warri River. Ben Miller Books Nigeria Ltd. 5: 34-55.

Imevbore AMA (1970). The Chemistry of the River Niger in the Kainji Reservoir Area. Arch Hyaorobiol. 67(3): 413-431.

Marine Pollution Bulletin (1986). The International Journal for Marine Environmentalists, Scientists, Engineers, Administrators, Politicians and Lawyers, 17(5): p. 230.

NEST (1991). Nigerians Threatened Environment. A National Profile. Nigerian Environmental Study/Action Team, A NEST Publication, $p$. 62-75.

Odiete TA, Bamuza EE (1994). Environmental Pollution with Notes on Solvent Extraction. Chem. pp. 38-42, 109-121.

World Health Organization (WHO) (1971). Limits for Substances and Characteristics Affecting the Acceptability of Water for Domestic Use. NY, (WHO Standard), p. 38. 